\title{
(3) Antibiotics gradient assay for V. natriegens
}

Franziska Müller ${ }^{1}$, Memduha Muratoglu ${ }^{1}$

${ }^{1}$ Phillips-Universität Marburg

Memduha Muratoglu

\section{open $\partial$ ACCESS}

\section{DOI:}

dx.doi.org/10.17504/protocol s.io.ps8dnhw

Protocol Citation: Franziska Müller, Memduha Muratoglu 2018. Antibiotics gradient assay for $\mathrm{V}$. natriegens. protocols.io

https://dx.doi.org/10.17504/p rotocols.io.ps8dnhw

License: This is an open access protocol distributed under the terms of the Creative Commons Attribution License, which permits unrestricted use, distribution, and reproduction in any medium, provided the original author and source are credited

Protocol status: Working We use this protocol and it's working

Created: Apr 27, 2018

Last Modified: Apr 27, 2018

PROTOCOL integer ID:

11840

1 Inoculate preculture of $V$. natriegens in LB3 medium $(3 \% \mathrm{NaCl})$ and incubate overnight at $37^{\circ} \mathrm{C}$, shaking. 


\section{Preparation of gradient plates}

2 Preparation of the first layer:

Place $11.5 \times 11.5 \mathrm{~cm}$ plates in an inclient position. The angle of inclination is such that the agar layer deminishes to nothing at one edge of the plate. Pour $30 \mathrm{ml}$ of LB3 with chosen antibiotics of concentrations to be tested into the plate. Let the agar solidify.

3 Switch position of the plate to an even surface and pour $30 \mathrm{ml}$ of LB3 agar without any antibiotics to onto the first layer. Let the agar solidify.

\section{Spotting of $\mathbf{V}$. natriegens}

$4 \quad$ Diltute the preculture to an OD550 of 0.1.

$5 \quad$ Pipette 8-10 spots of $5 \mu$ l of the culture along the gradient.

6 Let the spots dry and incubate the plates upside-down at $37^{\circ} \mathrm{C}$ over night or at room temperature over the weekend.

\section{Measurement}

7 Measure the distance from the edge of the agar plate to the last point of growth.

8 Calculate the highest concentration were $V$. natriegens can survive by using the following equation:

cantibioticH $=$ cantibioticmax $^{*} \mathrm{~d}_{\text {growth }} / \mathrm{d}_{\text {plate }}$ 
$\mathrm{C}_{\text {antibioticH: }}$ : highest antibiotic concentration $V$. natriegens can survive

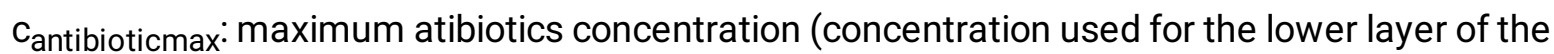
plate)

$d_{\text {growth: }}$ distance from the edge of the agarplate to the last point of growth

$d_{\text {plate }}$ length of the plate $(11.5 \mathrm{~cm})$ 